\title{
Microstructural Characters of Lyctinae and Dinoderinae (Coleoptera: Bostrichidae)
}

\author{
Lan-Yu Liu ${ }^{1,2}$ \\ ${ }^{1}$ Department of Education, National Museum of Natural Science, One Guancian Road, Taichung 404, Taiwan \\ ${ }^{2}$ National Central Library, 20 Chungshan S. Rd. Taipei 10001, Taiwan
}

Correspondence should be addressed to Lan-Yu Liu, liulysky@gmail.com

Received 21 March 2010; Revised 31 May 2010; Accepted 7 June 2010

Academic Editor: Arthur G. Appel

Copyright (C) 2010 Lan-Yu Liu. This is an open access article distributed under the Creative Commons Attribution License, which permits unrestricted use, distribution, and reproduction in any medium, provided the original work is properly cited.

Thirty-three species belonging to the bostrichid subfamilies Lyctinae and Dinoderinae were examined by low vacuum ESEM without sputtering. Eight types of microsculpture, five types of hair insertion, and 14 types of hair were found on the elytral disc and declivity. The different types of microstructure are described and illustrated with ESEM photos of each type. Surface microstructures provide additional taxonomically useful characters which can help to distinguish easily confused species. The study also showed that specimens can be examined under ESEM without any damage.

\section{Introduction}

The quality and number of characters is often a limiting factor in phylogenetic investigations. Thus, searching for new sets of characters is an important task in taxonomy. It is influenced both by detailed knowledge of the animals under investigation and by new techniques. In this study, the Environmental Scanning Electronic Microscope (ESEM) has been used to investigate microstructural characters of the cuticular surface of bostrichid beetles. Characters, such as hair, punctures, and tubercles, which are of significant value both to practical taxonomic work, and to further phylogenetic investigations of the Bostrichidae are illustrated.

The family Bostrichidae has a world-wide distribution but is mainly found in tropical and arid areas. There are more than 550 known species which vary from small to very large in size. The classification used in this paper is that of the recent catalogue of the family [1]. Bostrichidae mainly feed on and breed in bamboo, timber, rattan, stored grain, and products made from bamboo and timber. Their recorded plant hosts extend to at least 30 families [2], and probably almost any family with woody species can be attacked. In this paper, species in two of the subfamilies of Bostrichidae: Lyctinae and Dinoderinae are considered. A few species of lyctines have become important pests of timber, wooden objects and ancient structures [3-5]. Some species of Dinoderinae are important pests of bamboo and stored grain $[3,4,6]$.

On average, Lyctinae have the smallest body size of all bostrichids. Because of their small size, lyctines, as well as the taxonomically difficult genus Dinoderus (Dinoderinae) [7] are quite difficult subjects for classical investigation by light microscopy and deserve detailed morphological investigation with ESEM. Other genera of Dinoderinae are not as difficult to identify as Dinoderus, but to provide a more comprehensive concept of the microstructural characters of the subfamily Dinoderinae, some dinoderines in other genera have been examined.

A report on the use of microstructures to separate four bostrichid species in the genera Minthea and Dinoderus was presented by Liu et al. [8]. The present paper expands that study to include a greater range of genera and species.

\section{Materials and Methods}

In order to avoid any damage to the specimens, an FEI (model: Inspect-S) Environmental Scanning Electron Microscope (ESEM) was used to examine the elytral cuticle of specimens. Specimens were not removed from their mounts or pins, nor was the surface of the specimens coated with gold or other metals (i.e., the specimens were investigated 
unsputtered). The settings of the ESEM were beam spot from $2.5 \mathrm{~nm}$ to $4.0 \mathrm{~nm}$, acceleration voltage between $15 \mathrm{kV}$ and $30 \mathrm{kV}$, and low vacuum between $0.6 \mathrm{mbar}$ and $0.8 \mathrm{mbar}$. Particular attention was paid to the middle part of the elytral disc.

Thirty-three species were examined as listed below. Specimens were loaned from the Natural History Museum, London or form part of the private collection of the author.

Lyctinae.

Lyctini

Lyctus africanus Lesne 1907

Lyctus brunneus (Stephens 1830)

Lyctus carbonarius Waltl 1832

Lyctus cinereus Blanchard 1851

Lyctus hipposideros Lesne 1908

Lyctus linearis (Goeze 1777)

Lyctus tomentosus Reitter 1879

Minthea bivestita Lesne 1937

Minthea obsita (Wollaston 1867)

Minthea reticulata Lesne 1931

Minthea rugicollis (Walker 1858)

Minthea squamigera Pascoe 1866

Trogoxylini

Cephalotoma perdepressa Lesne 1937

Trogoxylon aequale (Wollaston 1867)

Trogoxylon angulicollis Santoro 1960

Trogoxylon impressum (Comolli 1837)

Trogoxylon parallelipipedum (Melsheimer 1846)

Trogoxylon praeustum (Erichson 1847)

Trogoxylon punctipenne (Fauvel 1904)

Dinoderinae.

Dinoderus bifoveolatus (Wollaston 1858)

Dinoderus brevis Horn 1878

Dinoderus distinctus Lesne 1897

Dinoderus minutus (Fabricius 1775)

Dinoderus ocellaris Stephens 1830

Dinoderus porcellus Lesne 1923

Dinoderus punctatissimus Lesne 1897

Prostephanus punctatus (Say 1826)

Prostephanus sulcicollis (Fairmaire \& Germain 1861)

Prostephanus truncatus (Horn 1878)

Rhyzopertha dominica (Fabricius 1792)

Stephanopachys quadricollis (Fairmaire in Marseul 1878)

Stephanopachys rugosus (Olivier 1795)

Stephanopachys substriatus (Paykull 1800)

\section{Results}

The lyctines do not have a distinct elytral declivity, but dinoderines do. Usually the patterns of punctures, tubercles and hairs on the elytral disc are different from those on the declivity, so the morphological patterns of microstructures on the elytral disc and on the declivity will be discussed separately for the Dinoderinae.

There are two basically different types of punctures in Lyctinae, hair-bearing and nonhair-bearing punctures. Hairbearing punctures always correspond in diameter to the root of the hair. Nonhair bearing punctures vary in size, depth and shape of the rim. Hence only nonhair bearing punctures of Lyctinae are discussed here.

Eight types of microsculpture, five types of hair insertion and 14 types of hairs were found on the elytral disc and declivity of the 33 species investigated. Short descriptions of the different types of microstructures observed are listed below. Each description corresponds to an ESEM photo (Figures 1, 2 and 3). In the captions to the figures, structures photographed on the elytral declivity are noted; all other photos are from the elytral disc.

Types of microsculpture:

Type a. Small subcircular puncture, moderately deep (Figure 1(a)).

Type b. Circular shallow puncture (Figure 1(b)).

Type c. Small elliptical puncture, moderately deep (Figure 1(c)).

Type d. Circular puncture with one or two deep pits inside (Figure 1(d)).

Type e. Shallow subcircular puncture with corrugated rim (Figure 1(e)).

Type f. Shallow subcircular puncture with corrugated rim and convex bottom (Figure 1(f)).

Type g. Subcircular puncture with irregular rim, moderately deep (Figure $1(\mathrm{~g})$ ).

Type h. Circular tubercle (Figure 1(h)).

Types of hair insertions:

Type a. Hair inserted away from microsculpture (Figures $1(\mathrm{a})-1(\mathrm{~d}))$.

Type b. Hair inserted next to a puncture (Figure 2(a)).

Type c. Hair inserted inside puncture and close to the rim (Figure 2(b)).

Type d. Hair inserted on top of a tubercle (Figure 2(c)).

Type e. Hair inserted on the side of a tubercle (Figure 2(d)).

Types of hairs:

Type a. Long thin smooth hair (Figure 3(a)).

Type b. Long smooth hair gradually tapering towards both base and apex (Figure 3(b)). 


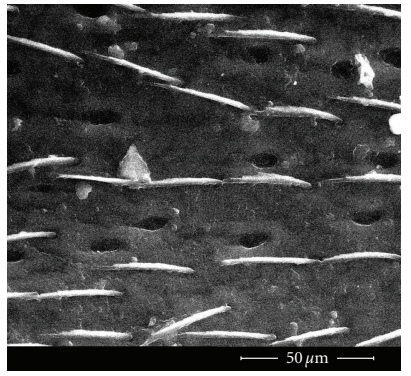

(a)

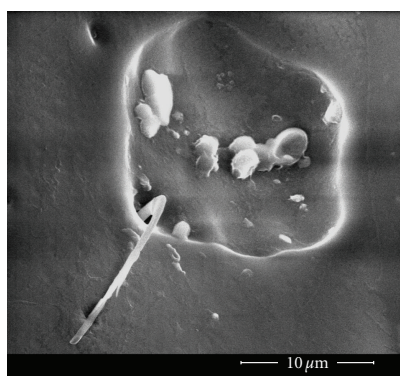

(e)

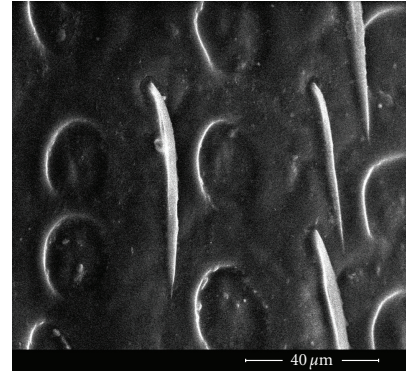

(b)

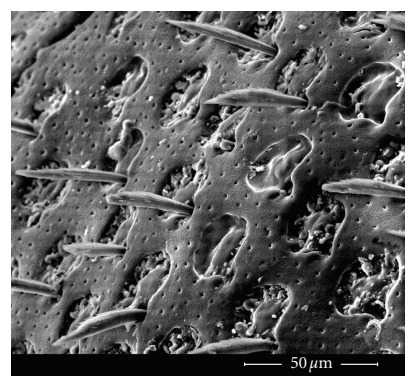

(f)

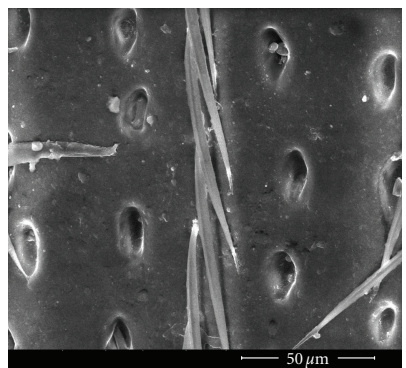

(c)

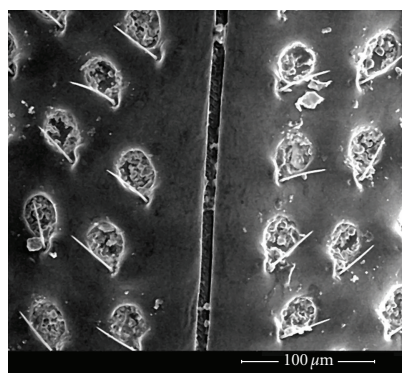

(g)

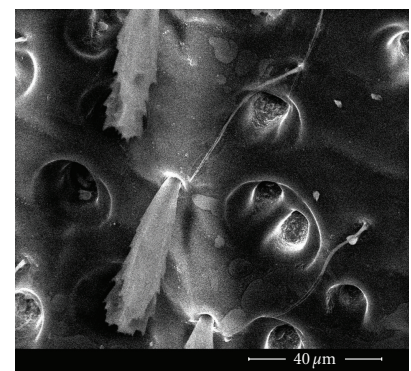

(d)

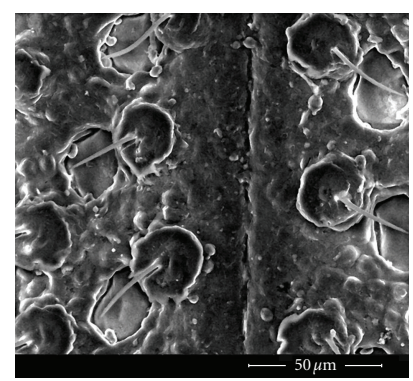

(h)

Figure 1: Microsculptures. (a) Trogoxylon impressum (Comolli 1837), (b) Minthea bivestita Lesne 1937, (c) Lyctus carbonarius Waltl 1832, (d) Minthea squamigera Pascoe 1866, (e) Dinoderus minutus (Fabricius, 1775), (f) declivity of D. minutus, (g) Stephanopachys substriatus (Paykull 1800), (h) Stephanopachys rugosus (Olivier 1795).

Type c. Long thin hair gradually tapering towards both base and apex, with one serrulate ridge (Figure 3(c)).

Type d. Moderately long and flat hair strongly tapering towards apex (Figure 3(d), arrows).

Type e. Short and flat hair strongly tapering towards apex (Figure 3(e), arrows).

Type $\mathrm{f}$. Long thin hair feathered on the apical half of one side (Figure 3(f)).

Type g. Stout hair with serrulate ridge on one side (Figure 3(g)).

Type h. Long and thick hair with serrulate sides (Figure 3(h)).

Type i. Long thick hair gradually tapering towards both base and apex, with 4 serrulate ridges (Figure 3(i)).

Type j. Long thick hair with forklike end (Figure 3(j), top)

Type k. Simple short hair (Figure 3(j), arrow).

Type 1. Stout hair with serrulate sides (Figure 3(k)).

Type m. Setae with an open brush-like end and 4-6 serrulate ribs (Figure 3(1)).

Type n. Lamelliform hair (Figure 3(l), arrow).

The distributions of the different types of microsculptures and hairs on the elytral disc and declivity vary greatly in the different species of lyctines and dinoderines. To give an overview, the distributions of the different types are presented in Tables 1 and 2.

In the subfamily Lyctinae, there are two types of punctures. The large shallow or deep one has no hair inside (microsculpture types a-d), the small one is hair-bearing.
The punctures which are nonhair-bearing are bigger, and in a more linear arrangement in the tribe Lyctini (Lyctus and Minthea in this study, Figures $1(\mathrm{~b})-1(\mathrm{~d})$ ) than in the tribe Trogoxylini (Trogoxylon in this study, Figure 1(a)). Cephalotoma is the only lyctine genus studied which has no nonhair bearing punctures.

Within Lyctinae, the hairs are usually thicker and more densely serrulate in the tribe Lyctini (Figures 3(a), 3(b), 3(i), and 3(1)) than in the tribe Trogoxylini (Figures 3(c)-3(e)). In this subfamily, Minthea (Figure 3(1)) and Cephalotoma (Figures 3(d) and 3(e)) clearly have two types of hairs whereas both Lyctus and Trogoxylon have only one type (Figures 3(a)-3(c), and 3(i)).

Minthea usually has two types of interstrial hairs on the elytra and a stria separates the two rows of different types of hairs (Figures 3(d) and 3(l)). The large erect hairs (type $\mathrm{m}$ ) are usually far more obvious than the fine and soft hairs on alternate interstriae (types $\mathrm{k}$ and $\mathrm{n}$ ). Only in M. bivestita, the second type of hair is as large as the major one. In this species the hairs are thicker and have 4 serrulate longitudinal ridges (type i).

The morphology of the hairs on Cephalotoma is very different from other species. There are two types of hairs on Cephalotoma, one is short, the other one is long, and both are strongly flattened upward from the insertion of the hair (Figures 3(d) and 3(e)). Hence, the morphology of the hairs clearly distinguishes Cephalotoma from other lyctines and dinoderines. Figures $3(\mathrm{~d})$ and $3(\mathrm{e})$ show both lateral and dorsal views of these special flat hairs.

In Dinoderus, usually the hair is inserted inside the puncture and close to the rim, or on a prominence on the rim 


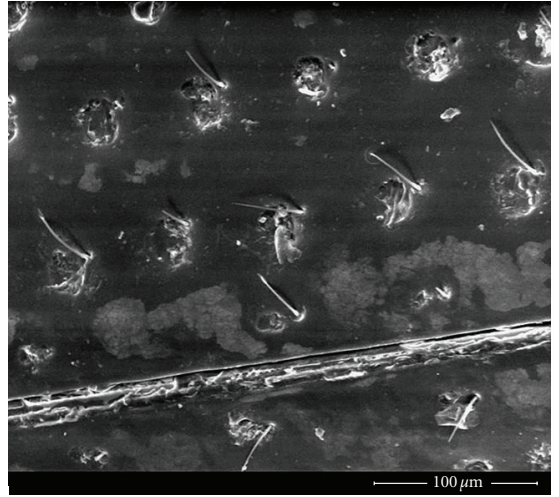

(a)

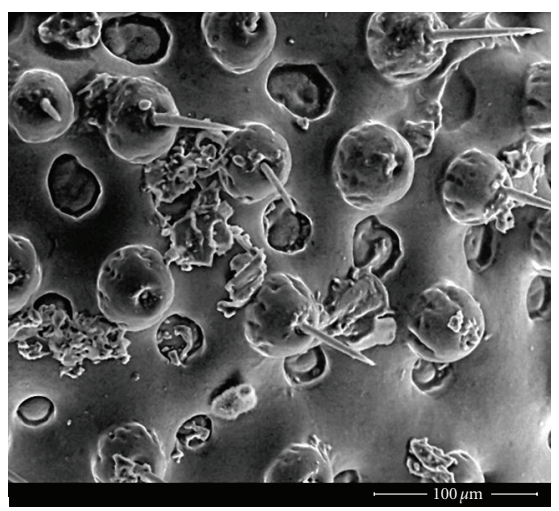

(c)

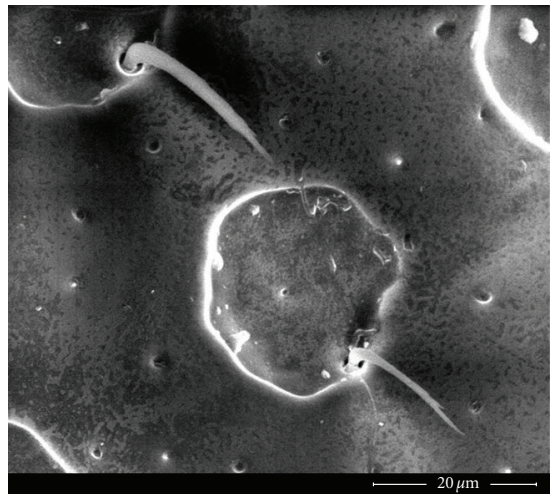

(b)

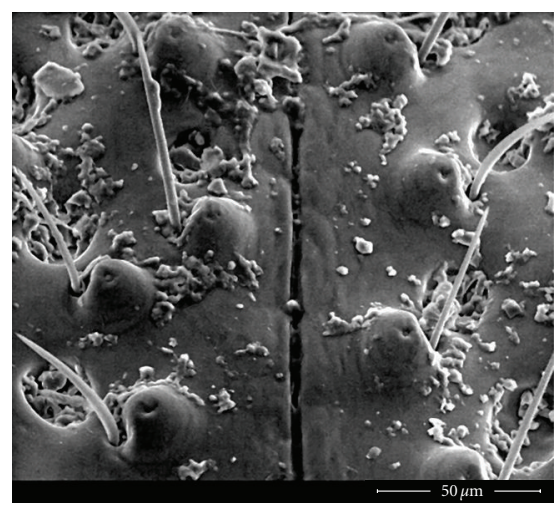

(d)

FIGURE 2: Insertions of hair. (a) Rhyzopertha dominica (Fabricius, 1792), (b) D. minutus, (c) declivity of Stephanopachys rugosus, (d) declivity of Stephanopachys substriatus.

of the puncture (hair insertion type c). Prostephanus has long simple hairs (hair type a) inserted on the rim of subcircular punctures (hair insertion type c). However, Stephanopachys has a tubercle next to each puncture (microsculpture type $g$ and $h$ ) and a simple hair on the top or side of the tubercle (hair type a and $\mathrm{k}$, and insertion of hair type $\mathrm{d}$ and $\mathrm{e}$ ). This suggests that the tubercle may have evolved from the prominence of the rim of the puncture.

With regard to the way in which the hairs are inserted, type a (away from the microsculpture) is found throughout the lyctines except for Cephalotoma. In C. perdepressa, hair insertion type c (inside puncture and close to the rim) is found and this is also present in Prostephanus and Dinoderus. In Rhyzopertha dominica, the insertion of the hairs is next to a puncture (type b). It is on the side of a tubercle (type e) in Stephanopachys quadricollis and on the top of a tubercle (type d) in S. rugosus. S. substriatus is the only species with a different insertion of its hair on elytral disc and declivity, next to a puncture (type b) on disc and on the side of a tubercle (type e) on declivity.

\section{Discussion}

Lesne $[9,10]$ and Gerberg [11] both examined the elytral sculpture of bostrichids, and used it to provide diagnostic characters for species. However, they did not examine the sculpture by ESEM, so they only found the larger microsculptural characters. Santoro [12] examined 31 species of Lyctinae under the light microscope by making the elytra transparent. He stated that the characters of punctures and hairs could be used to determine most of them at species level. However, his method requires the removal of the elytra and their treatment with potassium hydroxide before mounting, and is not suitable for rare or type specimens.

ESEM facilitates the examination of the microstructures on specimens. Not only the microsculpture, but also the shape of hairs, and the details of their insertion can be observed well under ESEM without any damage to the specimens. It is evident that microstructural characters can help to distinguish easily confused species and should be considered in future investigations.

4.1. Microsculptures on the Elytra of Lyctinae. In the subfamily Lyctinae, the nonhair bearing punctures are usually large and shallow apart from Minthea squamigera, which is the only species with very deep pits in the punctures (type d). Santoro [12] found there are two types of punctures on the elytra of $M$. squamigera, "single" and "double" in which two punctures seem to have fused. The ESEM picture of $M$. squamigera shows the two types of punctures (Figure 1(d)). 


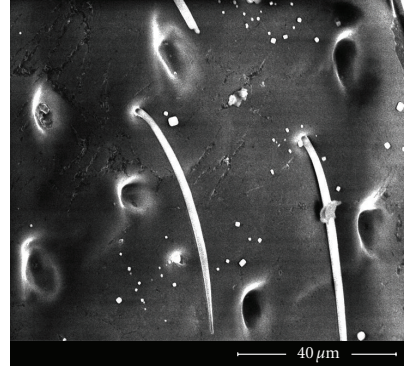

(a)

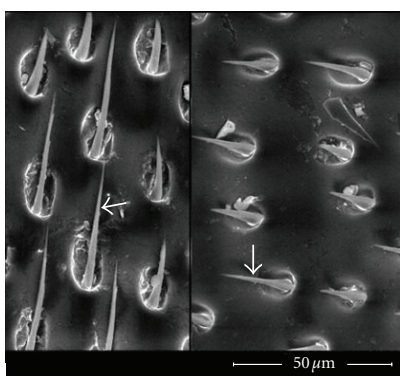

(d)

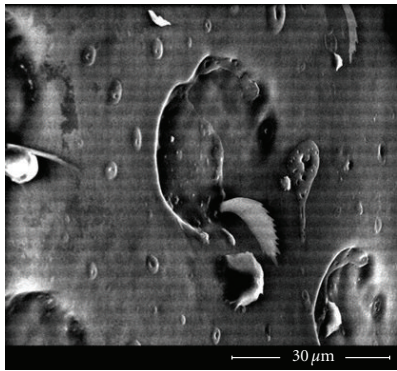

(g)

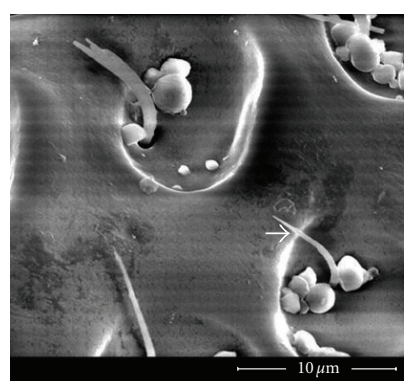

(j)

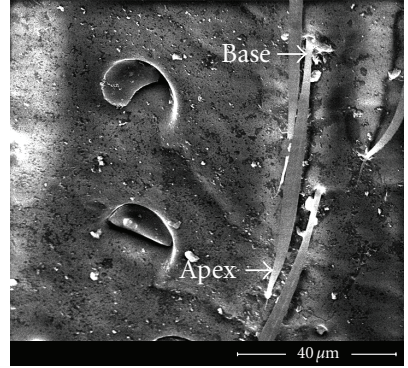

(b)

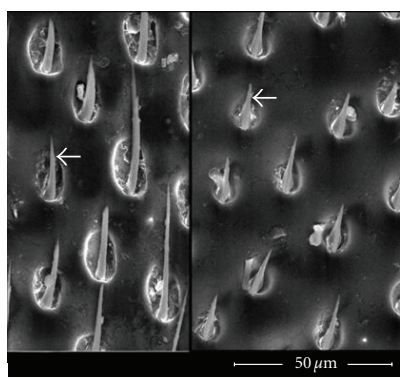

(e)

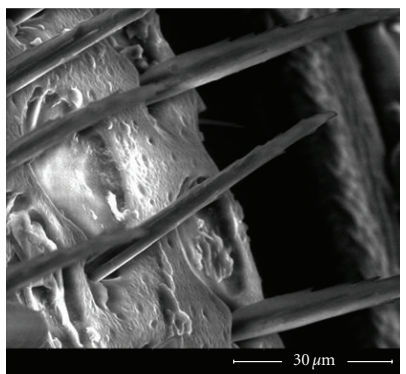

(h)

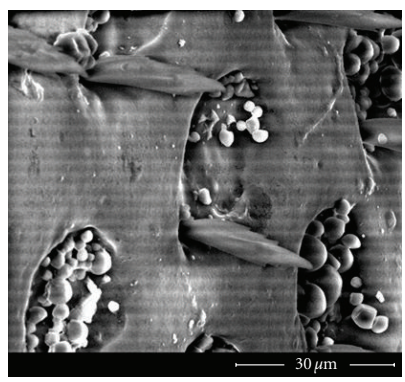

(k)

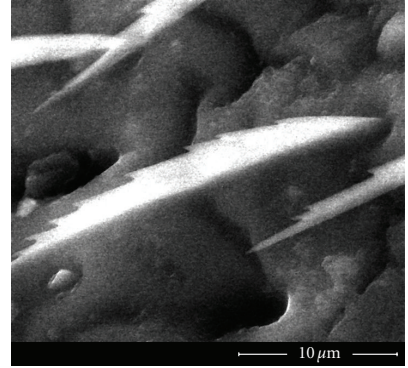

(c)

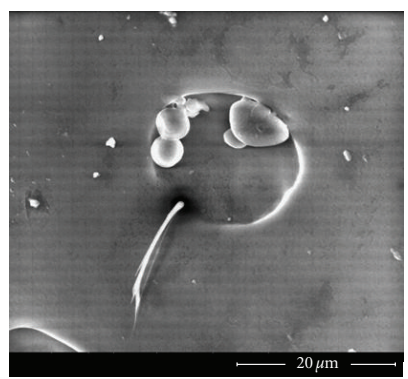

(f)

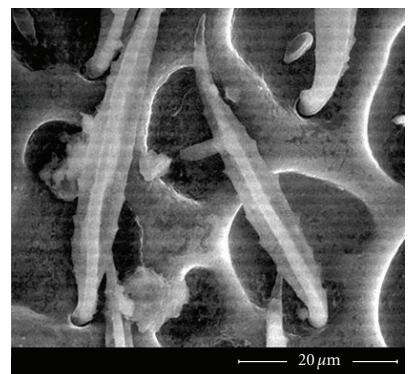

(i)

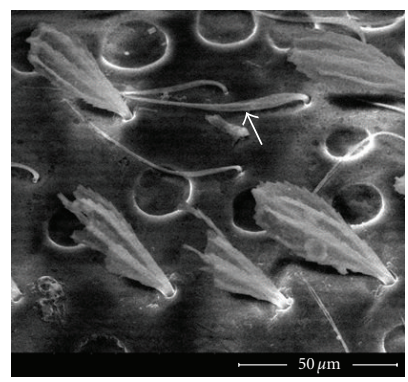

(1)

Figure 3: Hairs. (a) Lyctus africanus Lesne 1907, (b) Lyctus cinereus Blanchard 1851, (c) Trogoxylon impressum, (d) and (e) Cephalotoma perdepressa Lesne 1937 (left-lateral view, right-dorsal view), (f) Dinoderus ocellaris Stephens 1830, (g) Dinoderus punctatissimus Lesne 1897, (h) declivity of Dinoderus distinctus Lesne 1897, (i) Lyctus tomentosus Reitter 1879, (j) Dinoderus bifoveolatus (Wollaston 1858), (k) declivity of D. bifoveolatus, (1) Minthea reticulata Lesne 1931.

The double punctures occur only in M. squamigera, and not in other species of Minthea (cf. also [12]). To sum up, M. squamigera has three types of punctures: hair-bearing small punctures, nonhair bearing single deep punctures and nonhair bearing double deep punctures.

The shallow punctures shown on the ESEM pictures usually correspond to those shown with a blurred rim in
Santoro's [12] pictures. M. squamigera has the deepest punctures (type d) in Lyctinae according to this study, and shows the most distinct rim in Santoro's photographs. Santoro [12] suspected the structure under the punctures to be different in the shallow and deep ones. It would be interesting to study this further using a Scanning Transmission Electron Microscope (STEM). 
TABLE 1: Distribution of the different types of microsculpture $(*$ : appear on elytra, D: appear on decilivity).

\begin{tabular}{|c|c|c|c|c|c|c|c|c|}
\hline Taxa & a. & b. & c. & d. & e. & f. & g. & h. \\
\hline L. africanus & & & $*$ & & & & & \\
\hline L. brunneus & & & $*$ & & & & & \\
\hline L. carbonarius & & & * & & & & & \\
\hline L. cinereus & & & $*$ & & & & & \\
\hline L. hipposideros & & $*$ & & & & & & \\
\hline L. linearis & & $*$ & & & & & & \\
\hline L. tomentosus & & $*$ & & & & & & \\
\hline M. bivestita & & $*$ & & & & & & \\
\hline M. obstita & & $*$ & & & & & & \\
\hline M. reticulata & & $*$ & & & & & & \\
\hline M. rugicollis & & $*$ & & & & & & \\
\hline M. squamigera & & & & * & & & & \\
\hline T. aequale & $*$ & & & & & & & \\
\hline T. angulicollis & $*$ & & & & & & & \\
\hline T. impressum & * & & & & & & & \\
\hline T. parallelopipedum & * & & & & & & & \\
\hline T. praeustum & * & & & & & & & \\
\hline T. punctipenne & $*$ & & & & & & & \\
\hline C. perdepressa & & & * & & & & & \\
\hline R. dominica & & & & & $*, \mathrm{D}$ & & & \\
\hline S. quadricollis & & & & & & & $*, \mathrm{D}$ & $*, \mathrm{D}$ \\
\hline S. rugosus & & & & & & & $*, \mathrm{D}$ & $*, \mathrm{D}$ \\
\hline S. substriatus & & & & & & & $*, \mathrm{D}$ & $\mathrm{D}$ \\
\hline P. punctatus & & & $\mathrm{D}$ & & $*$ & & & \\
\hline P. sulcicollis & & & $\mathrm{D}$ & & $*$ & & & \\
\hline P. truncatus & & & $\mathrm{D}$ & & $*$ & & & \\
\hline D. bifoveolatus & & & & & $*, \mathrm{D}$ & & & \\
\hline D. brevis & & & & & $*$ & $\mathrm{D}$ & & \\
\hline D. distinctus & & & & & $*, \mathrm{D}$ & & & \\
\hline D. minutus & & & & & $*$ & $\mathrm{D}$ & & \\
\hline D. ocellaris & & & & & $*, \mathrm{D}$ & & & \\
\hline D. porcellus & & & & & $*, \mathrm{D}$ & & & \\
\hline D. punctatissimus & & & & & $*, \mathrm{D}$ & & & \\
\hline
\end{tabular}

The complete scientific name of each species is given in the list of material.

4.2. Hairs on the Elytra of Lyctinae. In Lyctinae, usually only one type of hair is found on the elytral disc, but Minthea and Cephalotoma both have two types of hairs on the elytral disc. The small, slender hairs in particular have been overlooked by most previous authors. Gerberg [11] mentioned the rows of the small hair only when he described Minthea obsita and $M$. rugicollis, but not when describing $M$. reticulata and $M$. squamigera. So his description of the rows of hair-each row of erect hair separated by two rows of large, circular, and shallow punctures - was somewhat misleading.

The descriptions of the hair on the elytra of Minthea differ among previous authors. Kraus [13] described the hair as "erect bristles", Lesne [14] described them as "erect claviform setae", and Gerberg [11] described them as "erect, flattened, whitish hair”. Santoro [12] classified Minthea into the group of Lyctinae with lanceolate or claviform hair. The type species, $M$. squamigera is even named for its scale-like hairs. The morphology of hairs on the elytra of Minthea becomes very clear under ESEM. The erect hair is not flattened at all. The major type of erect hair on the elytra of Minthea is the seta with an open brush-like end and 46 serrulate longitudinal ribs (type $\mathrm{m}$ ). Hence, the shape of the major hair is similar to the stout claviform hair with a densely divided tip, not scale-like or lanceolate.

Only one species of Cephalotoma has been examined in this study. There are three species in the genus Cephalotoma and four species in the closely related genus, Lyctoderma. Even though the morphology of the hairs on the elytral disc of $C$. perdepressa distinguishes it from other lyctines very well, further studies are needed to clarify the morphology of the hairs in both genera. This will certainly help to evaluate the phylogenetic relationships between these two genera and other lyctines. 
TABLE 2: Distribution of the different types of hairs (*: appear on elytra, D: appear on decilivity).

\begin{tabular}{|c|c|c|c|c|c|c|c|c|c|c|c|c|c|c|}
\hline Taxa & a. & b. & c. & d. & e. & f. & g. & h. & i. & j. & $\mathrm{k}$. & 1. & $\mathrm{~m}$. & $\mathrm{n}$. \\
\hline L. africanus & $*$ & & & & & & & & & & & & & \\
\hline L. brunneus & $*$ & & & & & & & & & & & & & \\
\hline L. carbonarius & * & & & & & & & & & & & & & \\
\hline L. cinereus & & * & & & & & & & & & & & & \\
\hline L. hipposideros & $*$ & & & & & & & & & & & & & \\
\hline L. linearis & & & $*$ & & & & & & & & & & & \\
\hline L. tomentosus & & & & & & & & & $*$ & & & & & \\
\hline M. bivestita & & & & & & & & & * & & & & $*$ & \\
\hline M. obstita & & & & & & & & & & & & & $*$ & $*$ \\
\hline M. reticulata & & & & & & & & & & & & & $*$ & $*$ \\
\hline M. rugicollis & & & & & & & & & & & $*$ & & $*$ & \\
\hline M. squamigera & & & & & & & & & & & $*$ & & $*$ & \\
\hline T. aequale & & & $*$ & & & & & & & & & & & \\
\hline T. angulicollis & & & $*$ & & & & & & & & & & & \\
\hline T. impressum & & & $*$ & & & & & & & & & & & \\
\hline T. parallelopipedum & & * & & & & & & & & & & & & \\
\hline T. praeustum & * & & & & & & & & & & & & & \\
\hline T. punctipenne & * & & & & & & & & & & & & & \\
\hline C. perdepressa & & & & $*$ & * & & & & & & & & & \\
\hline R. dominica & & & & & & & & & & & $*, \mathrm{D}$ & & & \\
\hline S. quadricollis & & & & & & & & & & & ${ }^{*}, \mathrm{D}$ & & & \\
\hline S. rugosus & $\mathrm{D}$ & & & & & & & & & & $*$ & & & \\
\hline S. substriatus & ${ }^{*}, \mathrm{D}$ & & & & & & & & & & & & & \\
\hline P. punctatus & ${ }^{*}, \mathrm{D}$ & & & & & & & & & & & & & \\
\hline P. sulcicollis & ${ }^{*}, \mathrm{D}$ & & & & & & & & & & & & & \\
\hline P. truncatus & ${ }^{*}, \mathrm{D}$ & & & & & & & & & & & & & \\
\hline D. bifoveolatus & & & & & & & & & & $*$ & $*$ & $\mathrm{D}$ & & \\
\hline D. brevis & & & & & & & $\mathrm{D}$ & & & $*$ & $*$ & & & \\
\hline D. distinctus & * & & & & & & * & $\mathrm{D}$ & & & & & & \\
\hline D. minutus & & & & & & $*$ & $\mathrm{D}$ & & & & $*$ & & & \\
\hline D. ocellaris & & & & & & $*$ & & $\mathrm{D}$ & & & & & & \\
\hline D. porcellus & & & & & & & $*$ & $\mathrm{D}$ & & & $*$ & & & \\
\hline D. punctatissimus & & & & & & & $*, \mathrm{D}$ & & & $*$ & & & & \\
\hline
\end{tabular}

The complete scientific name of each species is given in the list of material.

4.3. Microstructural Characters on the Elytra of Dinoderinae. The type of puncture differs between the elytral disc and declivity in Dinoderus brevis and D. minutus. There are shallow subcircular punctures with a corrugated rim (type e) on the disc, and shallow subcircular punctures with corrugated rim and convex inside (type f) on the declivity. Other Dinoderus spp. all have the type e puncture on both elytral disc and declivity. The difference in the punctures was not discussed in Lesne's [15] paper, but is briefly mentioned in Fisher's [16] revision.

There are usually two different types of hair on the elytral disc and a third type of hairs on the declivity in Dinoderus (see Table 2). No previous author mentioned the difference in the types of hair on the disc and on the declivity.
Fisher [16] described the hairs of Dinoderus as "short, erect, rather stiff, yellowish hair", Lesne [15] simply described the hairs of $D$. distinctus as "very short". Of the two types of hair usually found on the elytral disc of Dinoderus, one type consists of fine simple hair (types a and $\mathrm{j}$ ) as mentioned by Fisher [16], the other has a densely divided forklike end and/or is serrulate on one side (types $f, g$, and $k$ ), and is usually longer and of greater diameter. The latter were not found by Fisher [16], nor by Lesne [15]. Some Dinoderus species have no fine simple hair on elytral disc, but nevertheless have two different types of hair of types $f, g$, or k.

Except for Stephanopachys, all dinoderines have only hair-bearing punctures in which the hair is inserted inside 
the puncture close to the rim. This character distinguishes Dinoderinae from Lyctinae.

\section{Conclusion}

The special advantages of the scanning electronic microscope are the possibility to depict three dimensional structures with a very large depth of focus, and the fact that the image is built up almost purely from the surface of the specimen (e.g., [17]). The apparently three-dimensional picture is very suitable to describe fine structures. For example, the broad hair of Minthea have often been described as scale-like hair before we examined them by ESEM. However, the ESEM showed the hair is not flat and scale-like at all, but a thick, ridged hair with an open brush-like end.

Usually biological specimens are sputtered with gold to produce a conducting coating on the surface to avoid charging, which is a well known problem to all those working with biological specimens using electron microscopy. It is usually not possible to sputter rare specimens or types, but the ESEM can be used to examine such specimens without coating them. The ESEM uses a low vacuum in the specimen chamber even though the acceleration voltage is not low. It produces clear images of the microstructures of the uncoated specimens. This study not only found additional taxonomically useful characters in the microstructures on the surface of specimens, but also showed that we can now examine specimens without any damage under ESEM.

\section{References}

[1] J. Borowski and P. Wȩgrzynowicz, World Catalogue of Bostrichidae (Coleoptera), Mantis, Olsztyn, Poland, 2007.

[2] D. Chu and W. Zhang, "The catalogue of bostrichidae in China," Plant Quarantine, vol. 11, no. 2, pp. 105-109, 1997.

[3] N. E. Hickin, Powder-Post Beetle, The Insect Factor in Wood Decay, St. Martin's Press, New York, NY, USA, 1975.

[4] S. D. Miura, R. K. Kigawa, T. E. Sano, and K. G. Yamano, The Illustrated Handbook of Pest in Cultural Properties, Independent Administrative Institution, National Research Institute for Cultural Properties, Tokyo, Japan, 2001.

[5] B. Yin and B.-Y. Cheng, "Occurrence, damage and control of indoor wood boring pests," Journal of Anhui Agricultural University, vol. 31, pp. 151-155, 2004.

[6] T. J. Spilman, "False powderpost beetles of the genus Dinoderus in North America (Coleoptera, Bostrichidae)," The Coleopterists Bulletin, vol. 36, pp. 193-196, 1982.

[7] J-M. Vrydagh, "Contribution à 1 'étude des Bostrychidae (Coleoptera Teredilia) VII. Le genre Dinoderus Stephens 1830," Mémoires de la Société Royale Entomologique de Belgique, vol. 17, pp. 495-513, 1955.

[8] L. Y. Liu, K. Schönitzer, and J. T. Yang, "Microstructural characters as a tool for taxonomy (Coleoptera: Bostrichidae: Minthea and Dinoderus)," Nachrichtenblatt der Bayerischen Entomologen, vol. 58, no. 3/4, pp. 58-61, 2009.

[9] P. Lesne, "Revision des Coléoptères de la famille des Bostrychides 3," Annales de la Société Entomologique de France, vol. 67, pp. 438-621, 1898.

[10] P. Lesne, "Revision des Coléoptères de la famille des Bostrychides 5," Annales de la Société Entomologique de France, vol. 75, pp. 445-561, 1906.
[11] E. J. Gerberg, "A revision of the new world species of powderpost beetles belonging to the family Lyctidae," USDA Technical Bulletin 1157, United States Department of Agriculture, Washington, DC, USA, 1957.

[12] F. H. Santoro, "Reconocimiento pro los puntos y pelos elitrales de los lictidos registrados o interceptados en America (InsectaColeoptera)," IDIA-Suplemento Forestal, no. 5, pp. 107-115, 1970, Buenos Aires.

[13] E. J. Kraus, "II. A revision of the powder-post beetles of the family Lyctidae of the United States and Europe," in Technical Papers on Miscellaneous Forest Insects, L. O. Howard, Ed., vol. 20 part III, pp. 111-138, United States Department of Agriculture, Bureau of Entomology, 1911.

[14] P. Lesne, "Les Coléoptères Bostrychides de l'Afrique Tropicale Française," in Encyclopédie Entomologique 3, p. 288, Les Presses Universitaires de France et Librairie Paul Lechevalier, Paris, France, 1924.

[15] P. Lesne, "Le Dinoderus distinctus Lesne et les espèces affines," Bulletin de la Société Entomologique de France, pp. 131-134, 1921.

[16] W. S. Fisher, A Revision of the North American Species of Beetles Belonging to the Family Bostrichidae, vol. 698, USDA Miscellaneous Publication, Washington, DC, USA, 1950.

[17] J. Selfa and K. Schönitzer, "Taxonomy of the European species of Neotypus Förster, [1869], with a key for their identification (Hymenoptera, Ichneumoninae, Listrodomini)," Entomofauna, vol. 15, pp. 469-480, 1994. 

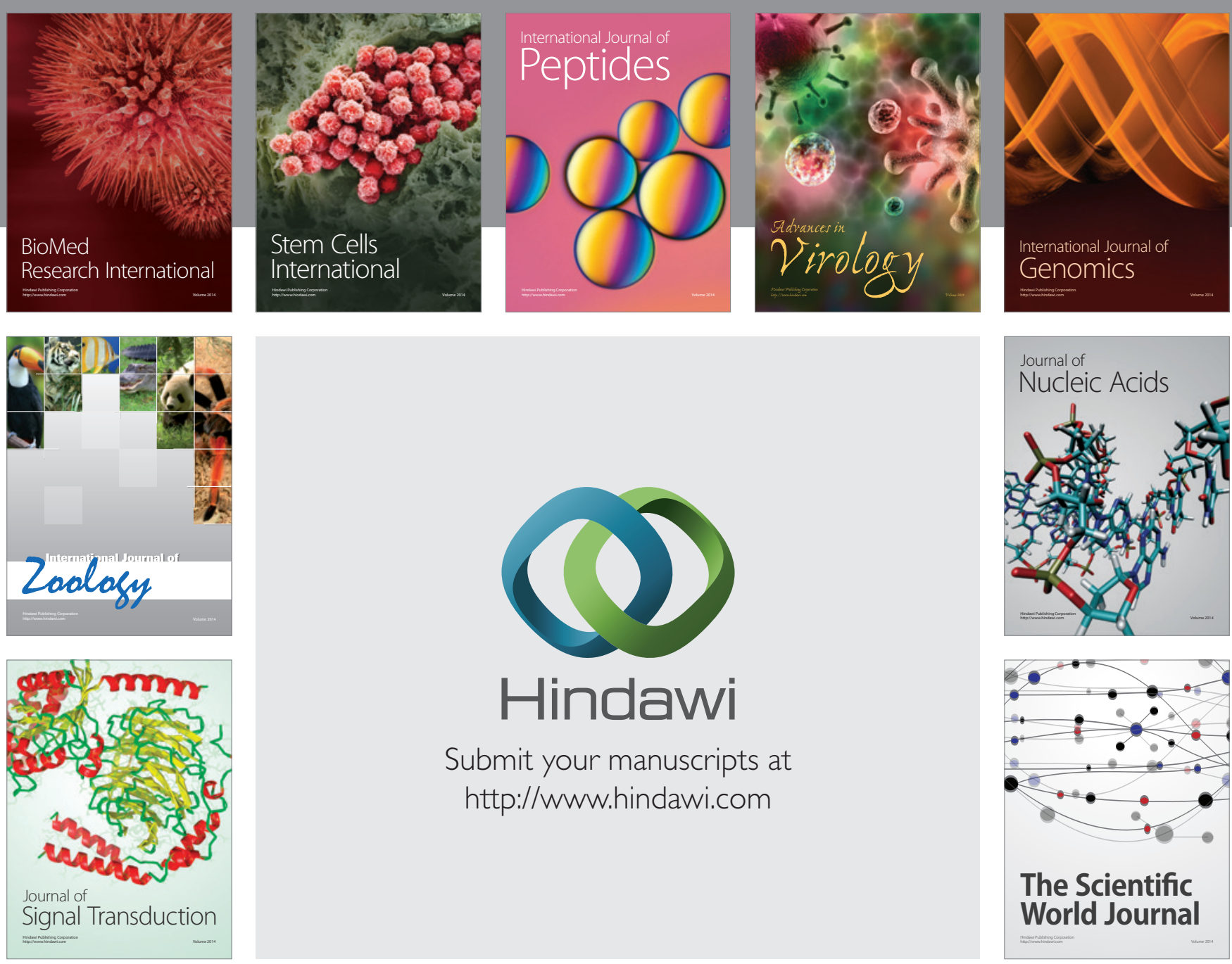

Submit your manuscripts at

http://www.hindawi.com
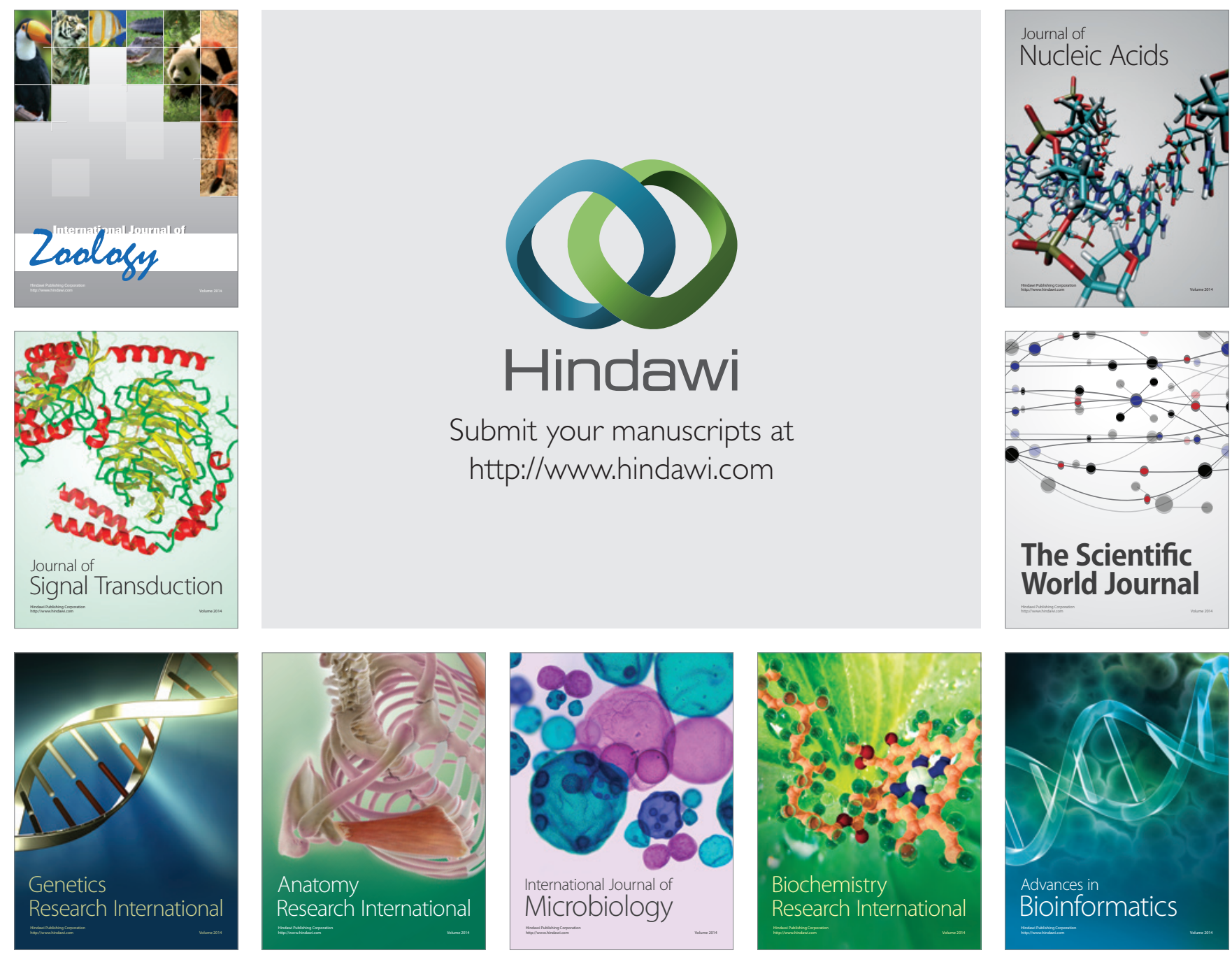

The Scientific World Journal
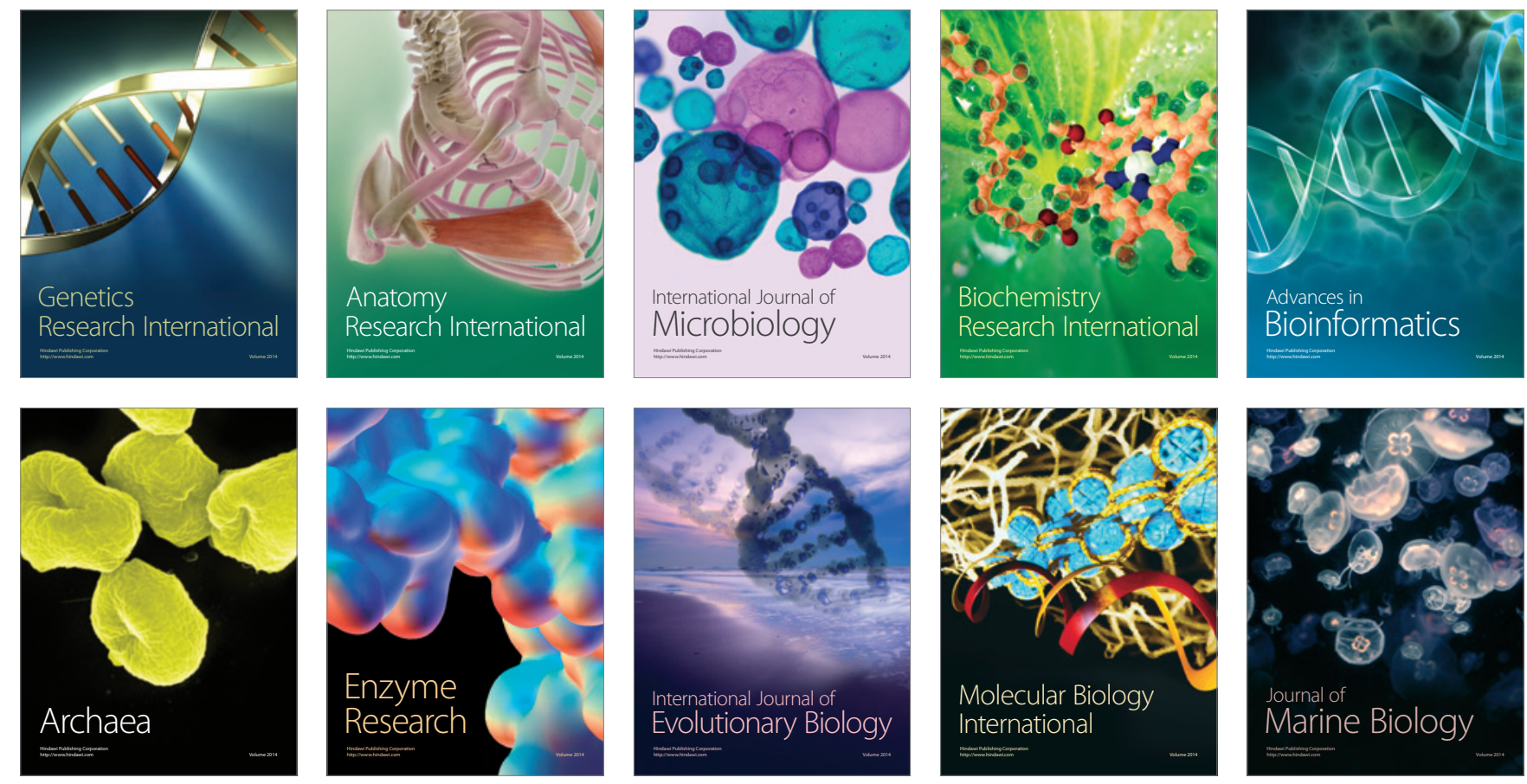